\title{
Occurrence and behavior of sulphur-bearing minerals in metallurgical coke
}

Stanislav Gornostayev, Eetu-Pekka Heikkinen, Jyrki Heino, and Timo Fabritius Process Metallurgy Research Unit, University of Oulu, BOX 4300, Oulu, 90014, Finland

\begin{abstract}
The behavior of sulphur-bearing minerals is characterized from coking coals to the feed coke and the blast furnace $(\mathrm{BF})$ coke using field emission scanning electron microscope and thermodynamic calculations. In coals, they are represented by sulphides (pyrite, sphalerite, galena, chalcopyrite and arsenopyrite) and sulphates (anhydrite and barite). During coking process, the minerals undergo phase transformations, but sulphur will be retained in the coke in mineral form for most of the minerals until the end of the coking process. Depending on the initial mineral in the coal, sulphurbearing minerals will be transformed at the end of coking process into the following phases: pyrrhotite, wurtzite, $\mathrm{Cu}-\mathrm{Fe}-\mathrm{S}$ melt, $\mathrm{CaS}$ and $\mathrm{BaS}$. The amount of sulphur that will be kept in the coke in mineral form increases in the following order: galena $\rightarrow$ pyrite $\rightarrow$ sphalerite $\rightarrow$ arsenopyrite $\rightarrow$ chalcopyrite $\rightarrow$ anhydrite $\rightarrow$ barite. Intensive gas flow under BF conditions facilitates liberation of sulphur from mineral phases in the Fe-S and $\mathrm{Zn}-\mathrm{S}$ system. $\mathrm{CaS}$ and $\mathrm{BaS}$ are the most stable sulphur-bearing phases formed after sulphur-bearings minerals. The coals with elevated amounts of anhydrite and barite, or with high concentrations of $\mathrm{Ca}$ and $\mathrm{Ba}$ combined with $\mathrm{S}$ should be avoided for coking purposes. Complete elimination of mineralrelated sulphur from coke under BF conditions occurs above 2000C.
\end{abstract}

Keywords: coke; minerals; sulphur; sulphides; sulphates 


\section{Introduction}

Metallurgical coke is one of the major components for a blast furnace (BF) process, acting as a fuel, a reducing and carburization agent, and a structural support material. Coke has a very complex chemical composition, and contains a wide range of elements, including various metals, sulphur, arsenic, and phosphorus [1-3].

Sulphur is considered an undesirable impurity in steels, and removal of sulphur-bearing inclusions is very complicated and costly [4-7]. Moreover, elevated concentrations of sulphur in the BF can cause the formation of liquid-phase $\mathrm{FeO}-\mathrm{FeS}$, which will extend the cohesive zone towards the $\mathrm{BF}$ top and decrease the gas permeability [8]. In addition to that, sulphur has a substantial negative environmental impact. For these reasons, the data on distribution and behavior of this element associated with all iron-making raw materials (ores, pellets) and fuels (coal, coke, oil) are important.

In coals, sulphur occurs in organic [9] and inorganic/mineral [10-14] form. The substantial part of sulphur associated with organic compounds can be removed from coals by heating [10], but some part of it, which is bonded with non-graphitic carbon, is heat-resistant at relatively high temperatures [11]. On the other hand, the behaviour of mineral-related sulphur under elevated temperatures (including coking and $\mathrm{BF}$ processes) is different and it depends on decomposition and transformations temperatures of sulphur-bearing minerals. We reported in a previous study [15] that the transformation of pyrite $\left(\mathrm{FeS}_{2}\right)$ to pyrrhotite $\left(\mathrm{Fe}_{1-x} \mathrm{~S}\right)$ during the coking process will cause transfer of pyrite-related sulphur to the BF, thus affecting the reactions there. However, the details of these reactions, the amount of mineral-related sulphur at the end of coking process, as well as the occurrence and behavior of other sulphur-bearing minerals during coking and BF processes have not been investigated. In particular, many features of phase transformations and decomposition of sulphur-bearing minerals (sulphur release) in carbon-dominated environment have not been studied in detail. In this paper we describe the results of the investigations of occurrence of major sulphurbearing minerals in coking coals and their transformations in the feed coke and in the BF process with special attention on the re-distribution of sulphur between the minerals and gas phase. 


\section{Tools and methods}

The samples of coals, feed coke and BF coke we obtained from SSAB Europe Ltd., Raahe, Finland. The coals are represented by Jas Mos coal from Poland, Willow Creek coal from Canada, Riverside coal from Australia and Severnaya-Vorkuta coal from Russia. The samples of BF coke were obtained by tuyere drilling. The length of the drill core (depth of drilling to the BF) was about 2 m. The supplied coals have, in general, relatively low content of sulphur, which usually do not exceed $0.5-0.6 \%$ (O. Kerkkonen, personal communication).

Polished sections of four types of coking coals (fractions $1-2.38 \mathrm{~mm}, 100+$ pieces per section) referred to above, metallurgical coke (rounded plates c. $20 \mathrm{~mm}$ in diameter) and BF coke (rounded plates c. $20 \mathrm{~mm}$ in diameter) have been investigated at the Center of Microscopy and Nanotechnology at the University of Oulu, Finland using Scanning Electron Microscope (SEM) Jeol GSM-6400 and Field Emission Scanning Electron Microscope (FESEM) Zeiss ULTRA plus equipped with an energy dispersive spectrometer (semi-quantitative EDS analysis used for mineral phases identification).

In addition to that, thermodynamics calculations were done with FactSage software [16] (version 7.1) in order to trace the behavior of mineral-related sulphur under coking and BF conditions as a function of temperature $\left(200-1200{ }^{\circ} \mathrm{C}\right.$ for the coking process, and $1000-2000{ }^{\circ} \mathrm{C}$ for the $\left.\mathrm{BF}\right)$. The conditions for the calculations were the same as we used for the investigation of the behavior of alkali-bearing minerals in metallurgical coke [17]. The compositions of the coke oven and BF gas were taken from Liao et al. [18] and Quinn et al. [19]. Stoichiometric compositions of sulphurbearing mineral phases were used as initial values for the calculations as they were presented in FactSage database [16]. The system for thermodynamic calculations was defined in order to simulate the conditions through which coke, including its minerals, undergoes during the coking and BF processes. It was considered as consisting of 100 grams of carbon, 100 grams of mineral (one at a time), 100 grams of gas for coke oven and $1 \mathrm{~g}$ of carbon, $1 \mathrm{~g}$ of minerals, and $100 \mathrm{~g}$ of gas for the BF (suggesting an intensive gas flow).

The purpose of thermodynamic calculations was to study whether there are driving forces for the changes in mineral compositions (i.e. whether reactions of certain compounds into other compounds are spontaneous or not). 


\section{Results and discussion}

\subsection{Occurrence of sulphur-bearing minerals in coking coals}

In order to understand better the behavior of sulphur-bearing minerals in the feed and BF coke, detailed characterization of their occurrence in a precursor material (coking coals) is needed. According to literature data, sulphur was found in a wide range of coal-associated minerals [10-14], which belong to two groups - sulphides and sulphates. The sulphides are represented by: pyrite, marcasite, pyrrhotite, sphalerite, galena, chalcopyrite, arsenopyrite, stibnite and millerite. The sulphates are: gypsum, bassanite, anhydrite, barite, coquimbite, rozenite, szomolnokite, natrojarosite, thenardite, glauberite, hexahydrite, and tshermigite. The investigations of our samples of coking coals with SEM, FESEM and EDS analysis have found the following sulphur-bearing minerals, namely pyrite, sphalerite, galena, chalcopyrite and anhydrite.

Pyrite is the most common sulphur-bearing mineral found in the samples. It occurs as separate grains or their aggregates in a coal matrix, or in association with other minerals (Figure 1a, Table 1). In some cases, sharp crystal edges of the mineral have been observed. The size of the aggregates varies from 10 to $50 \mu \mathrm{m}$, while individual crystals are 5-10 $\mu \mathrm{m}$ in size. 


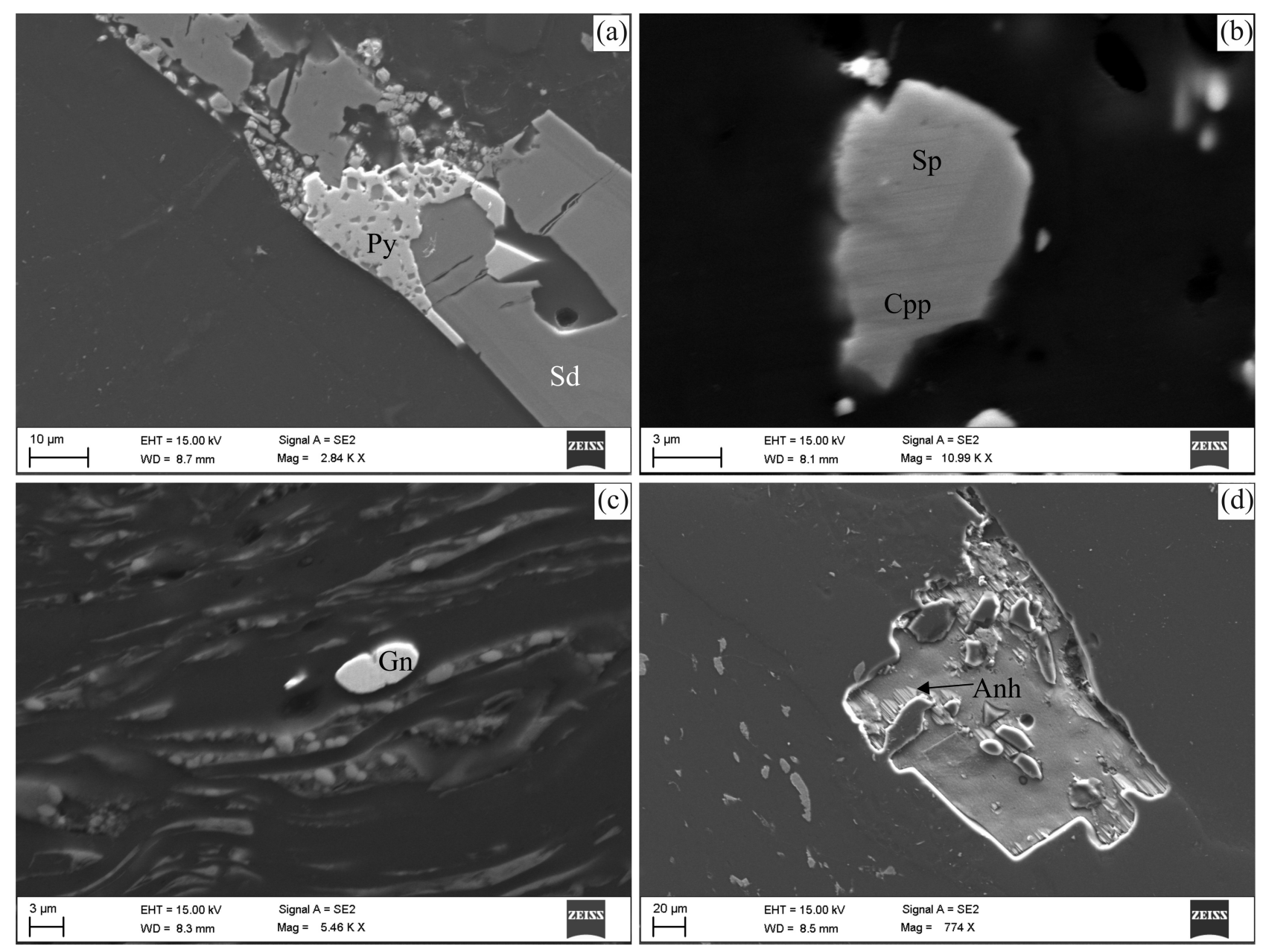

Figure 1. FESEM images of sulphur-bearing minerals in coking coals. Py - pyrite, Sp - sphalerite, $\mathrm{Cpp}$ - chalcopyrite, $\mathrm{Gn}$ - galena, Anh - anhydrite, $\mathrm{Sd}$ - siderite, ideally - $\mathrm{CaMg}\left(\mathrm{CO}_{3}\right)_{2} .1 \mathrm{a}$ - Jas $\mathrm{Mos}$ coal, Poland; 1b - Willow Creek coal, Canada; 1c - Riverside coal, Australia; 1d - Jas Mos coal, Poland. Abbreviations for the names of the minerals are given according to Whitney and Evans [20].

Sphalerite occurs in the coals in the form of single grains of up to $10 \mu \mathrm{m}$ in size and, more rarely, in association with chalcopyrite (Figure 1b, Table 1). In the latter case, it forms euhedral crystals of 3-5 $\mu \mathrm{m}$ in size enclosed by irregularly shaped (xenomorphic) chalcopyrite. Galena has been found in small $(3 \times 6 \mu \mathrm{m})$ elongated grains with smooth (rounded) outlines enclosed in a coal matrix between thin $(<2 \mu \mathrm{m}$ ) layers of aluminosilicates (Figure 1c, Table 1). Anhydrite forms relatively large (up to $200 \mu \mathrm{m}$ in size) flakes, which have tabular shape with linear outlines (Figure 1d, Table 1). 
Table 1. Representative EDS analysis (wt. \%, normalized) of some sulphur-bearing minerals in selected coking coals

\begin{tabular}{c|l|l|l|l|l|l|l}
\hline Index & $\mathrm{S}$ & $\mathrm{Fe}$ & $\mathrm{Zn}$ & $\mathrm{Pb}$ & $\mathrm{Cu}$ & $\mathrm{Ca}$ & $\mathrm{O}$ \\
\hline 1a-Py & 55.91 & 44.09 & & & & & \\
1b-Sp & 31.63 & 1.01 & 67.35 & & & & \\
1b-Cpp & 34.70 & 25.89 & & & 39.41 & & \\
1c-Gn & 14.79 & & & 85.21 & & & \\
1d-Anh & 25.42 & & & & 25.15 & 22.59 & 49.43 \\
\hline
\end{tabular}

Note: 1a-Py - pyrite, Jas Mos coal, Poland (Figure 1a); 1b-Sp - sphalerite, Willow Creek coal, Canada (Figure 1b); 1b-Cpp - chalcopyrite, Willow Creek coal, Canada (Figure 1b); 1c-Gn - galena, Riverside coal, Australia (Figure 1c); 1d-Anh - anhydrite, Jas Mos coal, Poland (Figure 1d). Abbreviations for the names of the minerals are given according to Whitney and Evans [20].

The data obtained during this study combined with the information from literature [10-14], indicate that from the range of sulphur-bearing minerals observed in coals, only some of them occur in substantial amounts. The other minerals can be classified as accessory (rare) phases. For that reason, rare minerals have not been considered for further investigation in this study. Pyrite and marcasite have the same chemical composition (formulae) $-\mathrm{FeS}_{2}$, and for the thermodynamic calculations only one phase (pyrite) has been chosen. Also, gypsum $\left(\mathrm{CaSO}_{4} \cdot 2 \mathrm{H}_{2} \mathrm{O}\right)$ and anhydrite $\left(\mathrm{CaSO}_{4}\right)$ have similar compositions. The crystalline water located in gypsum will be removed at 192 ${ }^{\circ} \mathrm{C}$ (this temperature corresponds to coal preheating stage) and the mineral will be transformed then to anhydrite [21]. Therefore, the following seven major coal-associated sulphur-bearing mineral phases have been selected for thermodynamic calculations for coking (feed coke) conditions: pyrite, sphalerite, galena, chalcopyrite, arsenopyrite, anhydrite, and barite. Their compositions and formula are given in Table 1 together with $\mathrm{CaS}$ and $\mathrm{BaS}$, which were used for the calculations under the $\mathrm{BF}$ conditions. The EDS data presented in Table 1 are slightly different from stoichiometric compositions listed in Table 2. For example, sphalerite from Yellow Creek coal contains 1.01\% of iron (Zn-Fe substitution). However, such deviations from stoichiometry are common for all natural mineral occurrences. As can be seen from Table 2, the amount of sulphur in major coal-associated minerals varies considerably (from 13.40 to $53.45 \mathrm{wt}$ \%), and increases in the order of: galena $\rightarrow$ barite $\rightarrow$ arsenopyrite $\rightarrow$ anhydrite $\rightarrow$ sphalerite $\rightarrow$ chalcopyrite $\rightarrow$ pyrite.

Table 2. Compositions (wt. \%) of some sulphur-bearing mineral phases used for the calculations 


\begin{tabular}{|c|c|c|c|c|c|c|c|c|c|c|}
\hline Mineral & $\mathrm{S}$ & $\mathrm{Fe}$ & $\mathrm{Zn}$ & $\mathrm{Pb}$ & $\mathrm{Cu}$ & As & $\mathrm{Ba}$ & $\mathrm{Ca}$ & $\mathrm{O}$ & $\begin{array}{l}\text { Formul } \\
\text { ae }\end{array}$ \\
\hline Py & 53.45 & 46.55 & & & & & & & & $\mathrm{FeS}_{2}$ \\
\hline $\mathrm{Sp}$ & 32.90 & & 67.10 & & & & & & & $\mathrm{ZnS}$ \\
\hline Gn & 13.40 & & & 86.60 & & & & & & $\mathrm{PbS}$ \\
\hline Ccp & 34.94 & 30.43 & & & 34.63 & & & & & $\mathrm{CuFeS}_{2}$ \\
\hline Apy & 19.69 & 34.30 & & & & 46.01 & & & & FeAsS \\
\hline $\mathrm{Brt}$ & 13.74 & & & & & & 58.84 & & 27.42 & $\mathrm{BaSO}_{4}$ \\
\hline Anh & 23.55 & & & & & & & 29.44 & 47.01 & $\mathrm{CaSO}_{4}$ \\
\hline Po & 37.67 & 62.33 & & & & & & & & $\mathrm{Fe}_{0.95} \mathrm{~S}$ \\
\hline Wur & 32.90 & & 67.10 & & & & & & & $\mathrm{ZnS}$ \\
\hline $\mathrm{CaS}$ & 44.45 & & & & & & & 55.55 & & $\mathrm{CaS}$ \\
\hline $\mathrm{BaS}$ & 18.93 & & & & & & 81.07 & & & $\mathrm{BaS}$ \\
\hline
\end{tabular}

Note: Py - pyrite, Sp - sphalerite, Gn - galena, Cpp - chalcopyrite, Apy - arsenopyrite, Brt barite, Anh - anhydrite, Po - pyrrhotite, Wur - wurtzite. Compositions are from Bale et al. [16]. Abbreviations for the names of corresponding minerals (excluding $\mathrm{CaS}$ and $\mathrm{BaS}$ ) are given according to Whitney and Evans [20]).

\subsection{Occurrence and behavior of sulphur-bearing minerals during the formation of metallurgical coke}

Under high-temperature conditions (up to $1200^{\circ} \mathrm{C}$ ) of coke oven, coal-associated minerals undergo phase transformations and decomposition, including decarbonation, dehydration, dehydroxylation, and desulphurization [22]. From sulphur-bearing minerals, only pyrrhotite and ZnS (most likely wurtzite) were observed in our samples of coke (Figure 2). Nevertheless, the investigation of behavior of pyrites during coal pyrolysis [11] has shown that carbon facilitates the decomposition of pyrite, but substantial desulphurization of coke may be achieved by heating to $1400^{\circ} \mathrm{C}$. It was also reported that temperatures c. $1600{ }^{\circ} \mathrm{C}$ are required for the complete remove of mineral sulphur from cokes. 

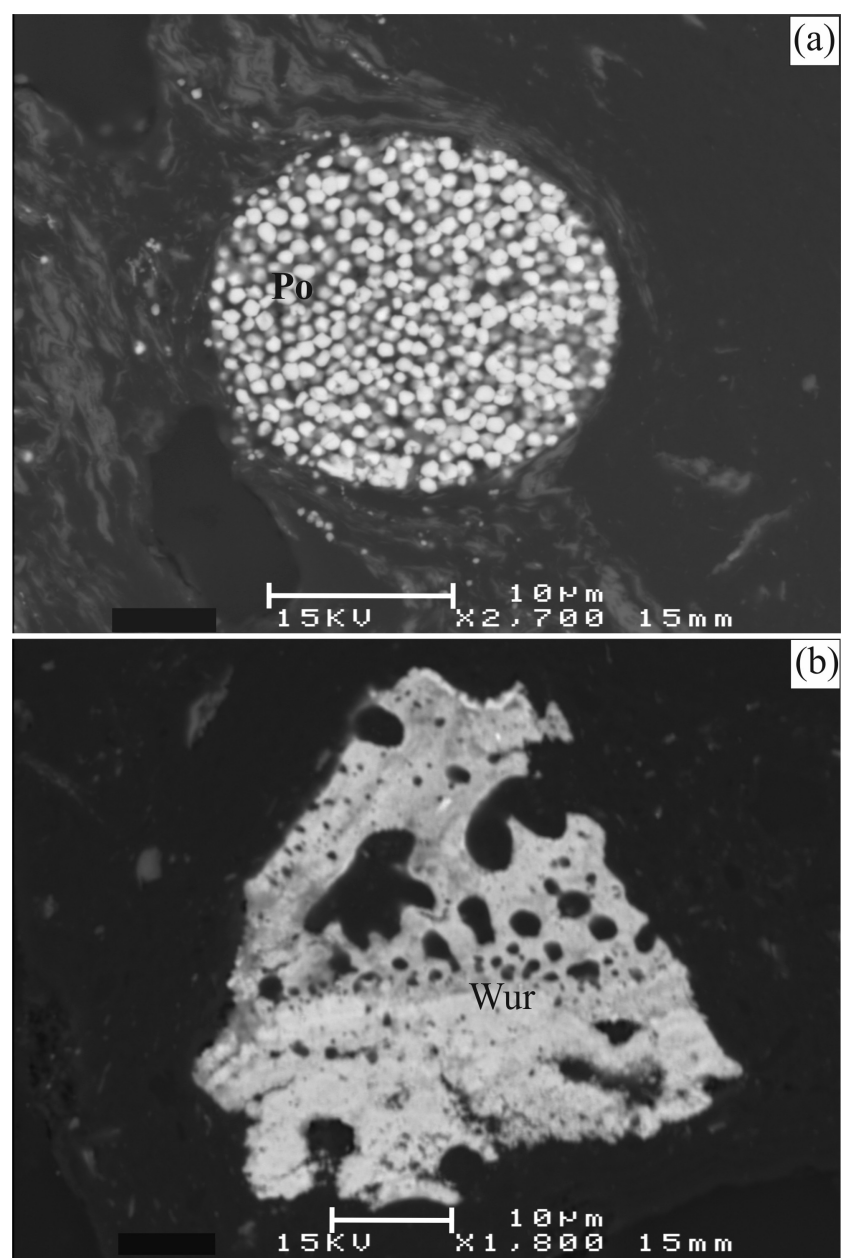

Figure 2. SEM images of sulphur-bearing mineral phases in the feed coke. (a) Po - pyrrhotite, (b) Wur - wurtzite. Abbreviations for the names of the minerals are given according to Whitney and Evans [20].

Our calculations have shown (Figure 3) that the behavior of sulphur-bearing minerals under coke oven conditions varies substantially, observing a number of phase transformations at different temperatures as well as different amounts of sulphur released toward the end of coking process. Unlike aluminosilicates $[17,22]$, most of the primary sulphides occurring in coals will decompose and/or transform to other phases at coking temperatures (Figure 3). For that reason, not all of them can be found in metallurgical coke in their primary form.

Pyrite transforms [15] to two pyrrhotite (Figure 2a) varieties, marked as FeS(s) and FeS(s2) on Figure 3a. The FeS(s2) variety is stable at high temperature until the end of coking process. It occurs in rounded aggregates consisting of tiny $(1-2 \mu \mathrm{m})$ equidimentional dipyramidal crystals (Figure 2a), keeping $50 \%$ of whole sulphur at $1200{ }^{\circ} \mathrm{C}$ (Figure $3 \mathrm{a}$ ).

Sphalerite transforms to wurtzite at $1020{ }^{\circ} \mathrm{C}$ (Figure $3 \mathrm{~b}$ ), retaining primary crystal outlines and hosting $52.39 \%$ of $\mathrm{S}$ at $1200{ }^{\circ} \mathrm{C}$ (the rest $47.61 \%$ is in the gas phase), while galena will decompose 
fully at $890{ }^{\circ} \mathrm{C}$ (solidification stage of coking process), thus releasing whole mineral-related sulphur to the gas phase.

Chalcopyrite provides the most complex phase transformations and compositional changes under coking conditions (Figure 3d) forming talnakhite, bornite and, at higher temperatures - iron sulphides, which will release all the sulphur into gas and $\mathrm{Cu}-\mathrm{Fe}-\mathrm{S}$ melt at the end of coke solidification stage. In case of arsenopyrite, iron sulphides will be formed and they will keep $78.87 \%$ of the whole sulphur in mineral form at $1200{ }^{\circ} \mathrm{C}$.

Both anhydrite and barite will fully decompose below $200^{\circ} \mathrm{C}$, but at higher temperatures close to the beginning of the solidification stage of coke $\left(600^{\circ} \mathrm{C}\right)$, the sulphides of $\mathrm{Ba}$ and $\mathrm{Ca}$ will be formed if sulphur is available in the system. These sulphides will keep all mineral-related sulphur at $1200^{\circ} \mathrm{C}$.

The data on the occurrence of mineral sulphur at $1200^{\circ} \mathrm{C}$ are summarized in Table 3 , from where the sulphur-bearing phases can be listed in the following order of the amount of S, which will be kept in the coke in mineral form: galena $\rightarrow$ pyrite $\rightarrow$ sphalerite $\rightarrow$ arsenopyrite $\rightarrow$ chalcopyrite $\rightarrow$ anhydrite $\rightarrow(=)$ barite. This fact leads to an important conclusion that the mineral located in the beginning of this list (galena) is more favorable for coking and BF process than those at the end of the list (anhydrite and barite). Therefore, coking coals with galena-associated sulphur are better than those with anhydrite- and barite-associated sulphur. The distinction between the minerals can be made by optical microscopy of coals. More generally, express chemical analysis can be applied, where high concentrations of $\mathrm{Ca}$ and $\mathrm{Ba}$ combined with $\mathrm{S}$ indicate the possibility of formation the formation of $\mathrm{CaS}$ and $\mathrm{BaS}$ during coking process. 
Figure

3. $\quad 120$
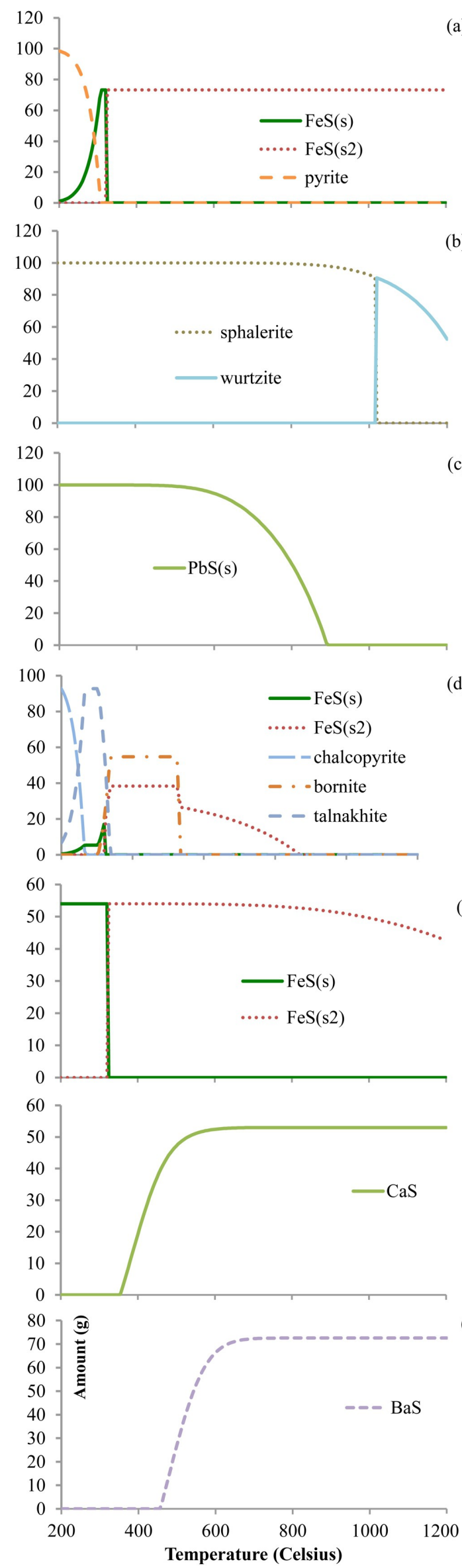

(c)

(d)

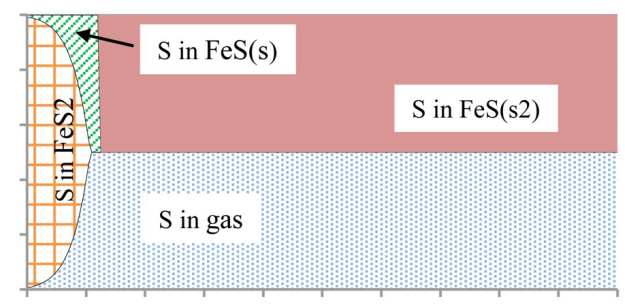

(b)

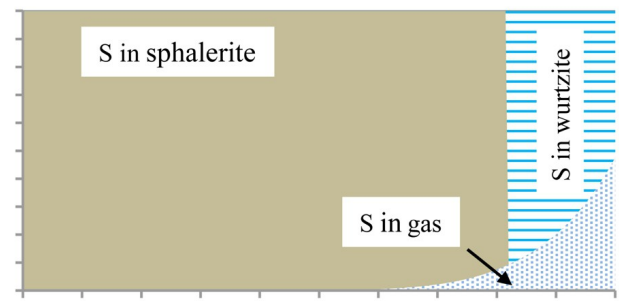

(c)
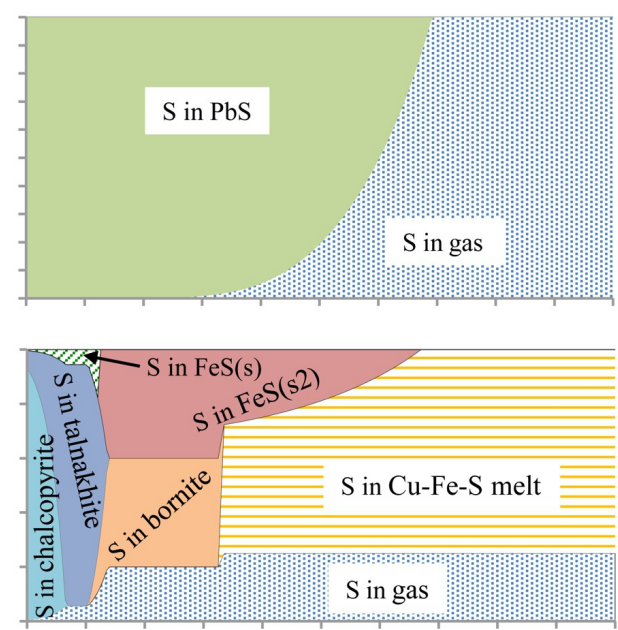

(e)

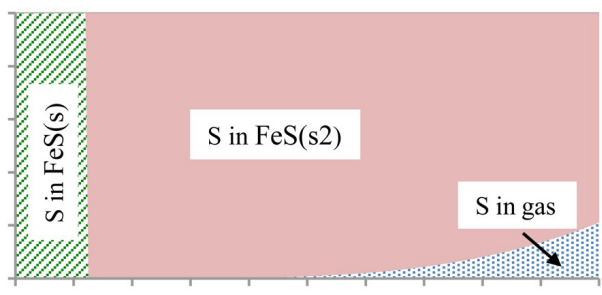

(f)

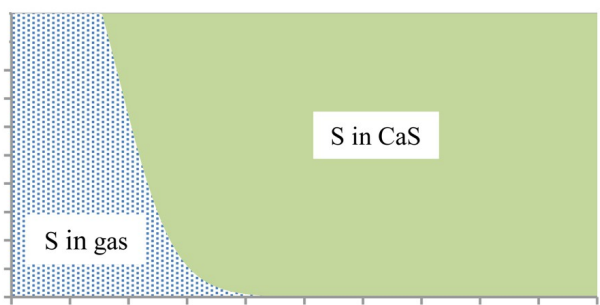

(g)

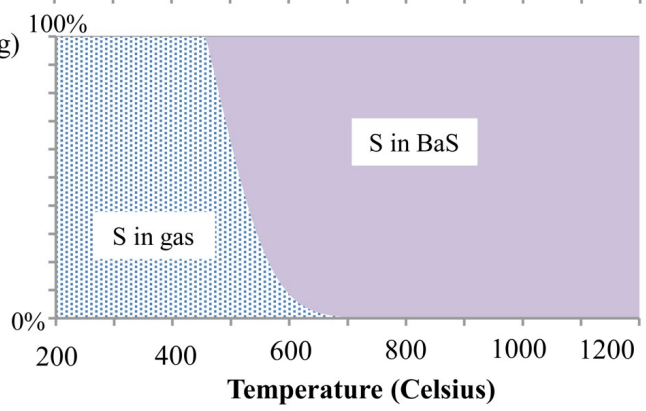

Transformations of suphur-bearing minerals (left column) and concentration of sulphur (right column) in mineral-carbon-gas system during the formation of coke. (a) - pyrite, (b) - sphalerite, (c) - galena, (d) chalcopyrite, (e) - arsenopyrite, (f) - anhydrite, (g) - barite. FeS(s) and FeS(s2) - pyrrhotite. 
Table 3. Amount of sulphur remained in mineral form at the end of coking process

\begin{tabular}{l|l}
\hline $\begin{array}{l}\text { Initial } \\
\text { mineral }\end{array}$ & $\begin{array}{l}\text { S in mineral form } \\
\text { at } 1200{ }^{\circ} \mathrm{C}, \text { wt. } \%\end{array}$ \\
\hline Galena & 0.00 \\
Pyrite & 50.00 \\
Sphalerite & 52.39 \\
Chalcopyrite & 74.99 \\
Arsenopyrite & 78.87 \\
Anhydrite & 100.00 \\
Barite & 100.00 \\
\hline
\end{tabular}

\subsection{Occurrence and behaviour of sulphur-bearing minerals in metallurgical coke under BF conditions}

Our earlier investigations of samples of BF coke (drilled from working BF) have shown that inorganic compounds were mostly presented by aluminosilicates and oxides [23, 24]. However, there are reports on $\mathrm{CaS}$ findings in the $\mathrm{BF}$ coke [25]. In order to expand understanding of the occurrence (mineral form) and behaviour of sulphur under BF conditions, thermodynamic calculations were done. The calculations were performed for the phases remained in the system at the end of coking process (see 3.2): pyrrhotite, wurtzite, $\mathrm{Cu}-\mathrm{Fe}-\mathrm{S}(37.94 \% \mathrm{Cu}, 33.34 \% \mathrm{Fe}, 28.72 \% \mathrm{~S})$ melt, $\mathrm{CaS}$ and $\mathrm{BaS}$.

The calculations have shown (Figure 4) that pyrrhotite, wurtzite and $\mathrm{Cu}-\mathrm{Fe}-\mathrm{S}$ melt, formed under coking conditions, will fully decompose (release sulphur to the gas phase) at temperatures below $1620{ }^{\circ} \mathrm{C}$ (Figures. 4 a, b and c). This statement is in agreement with the data reported by Patrick [11]. The behaviour of Ca- and Ba-associated sulphur was, however, quite different (Figures. 4d and 4e). BaS will start melting only at c. $1715^{\circ} \mathrm{C}$, with simultaneous release of sulphur to the gas phase. At $2000{ }^{\circ} \mathrm{C}, 64.6$ wt.\% of sulphur will still be remained in mineral form (BaS melt). As for CaS, this solid compound will start releasing sulphur somewhere near $1750{ }^{\circ} \mathrm{C}$, and it will keep about $83 \%$ of sulphur in mineral form at $2000{ }^{\circ} \mathrm{C}$. These data indicate that $\mathrm{CaS}$ and $\mathrm{BaS}$ are the most stable sulphur-bearing phases under BF conditions. 


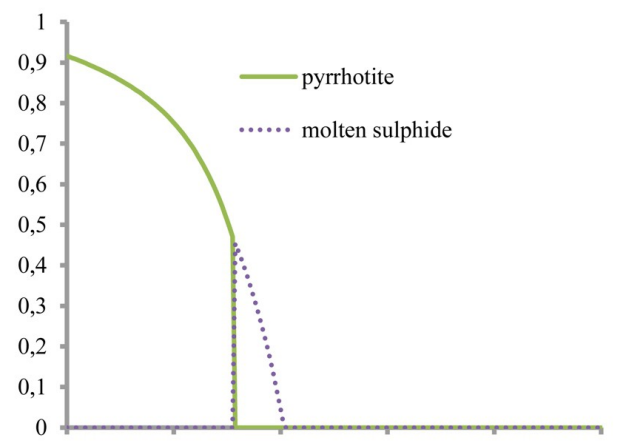

(a)
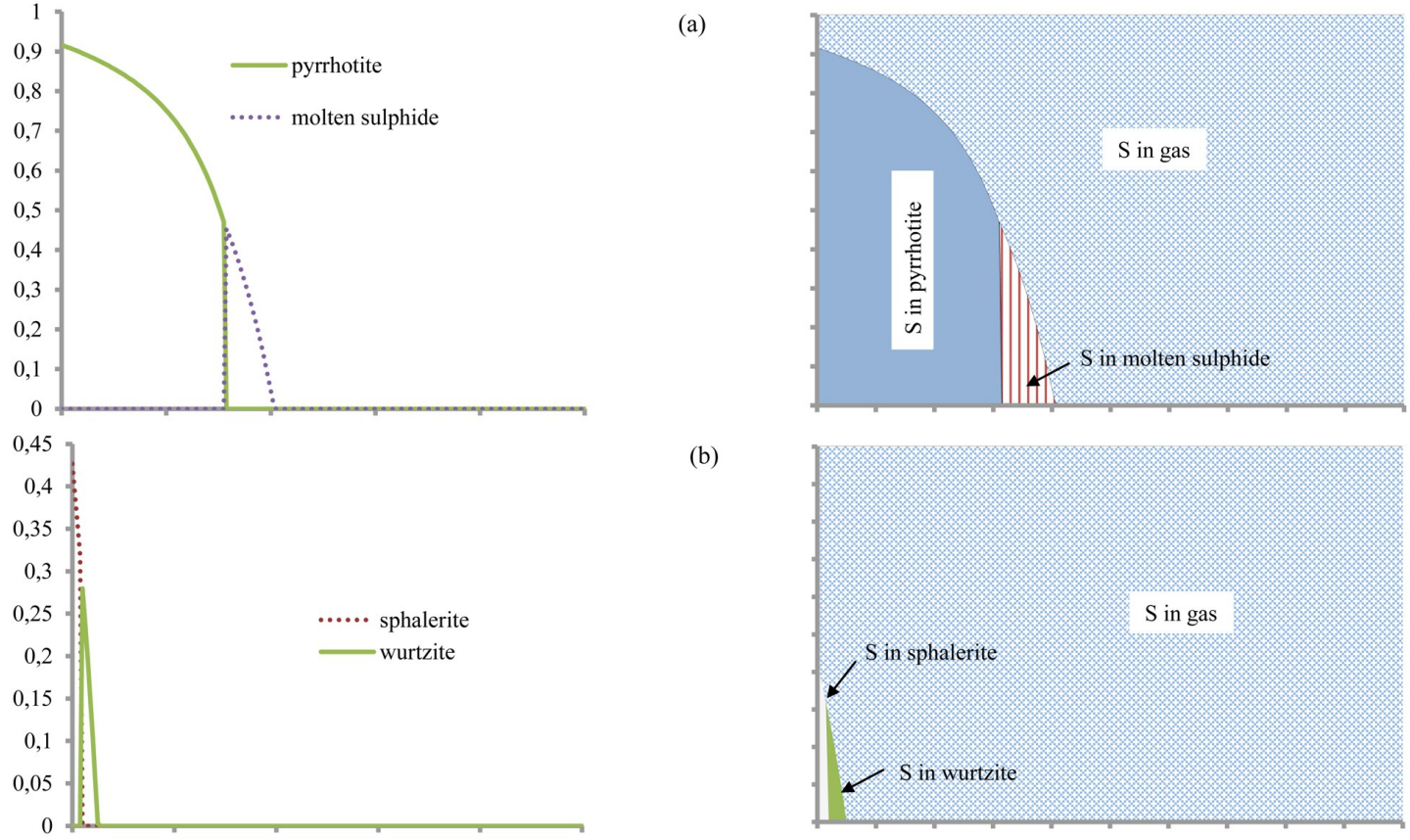

(b)

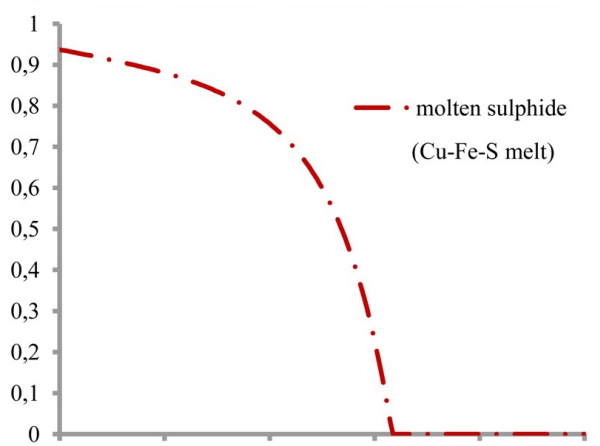

(c)
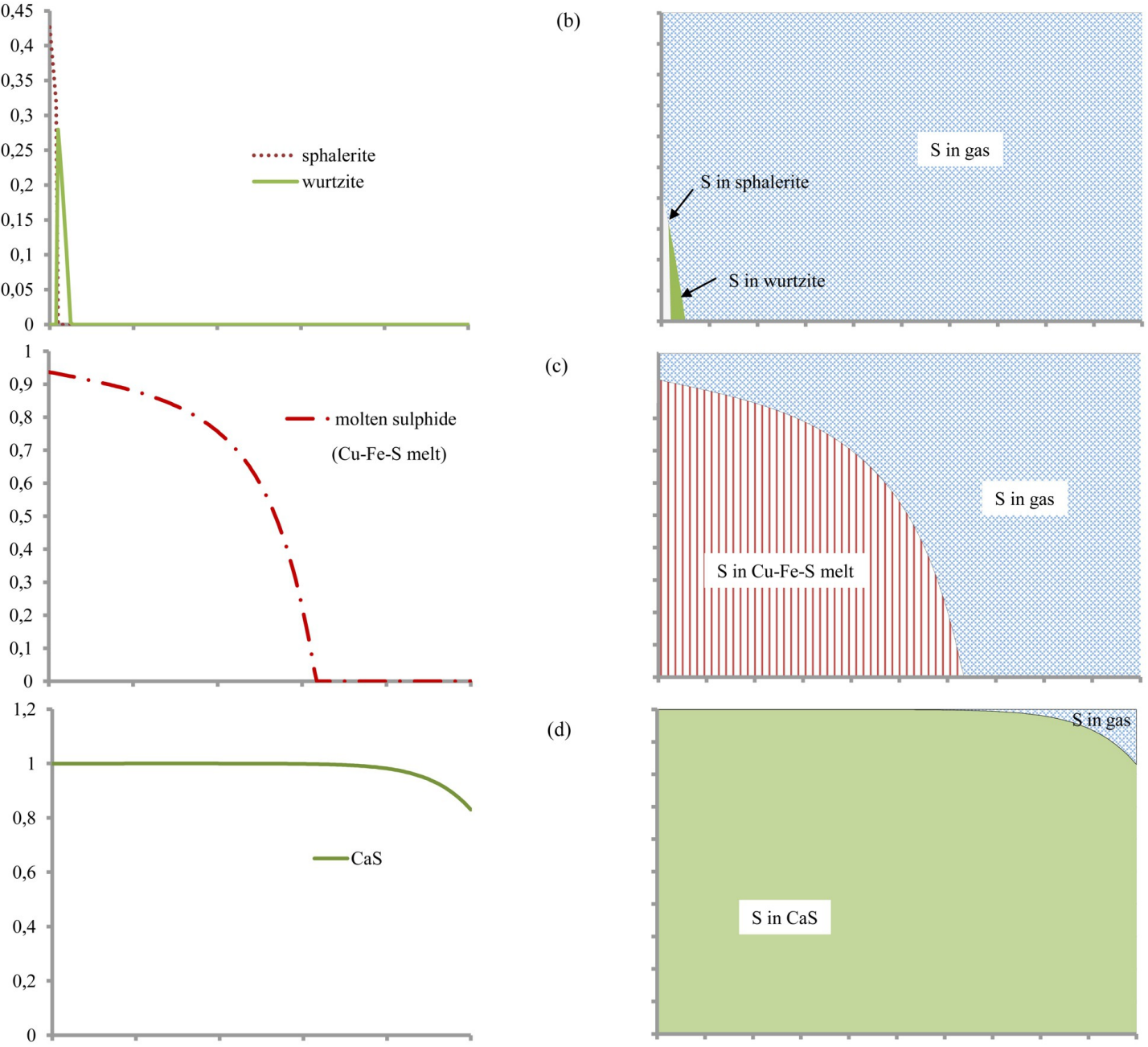

(d)
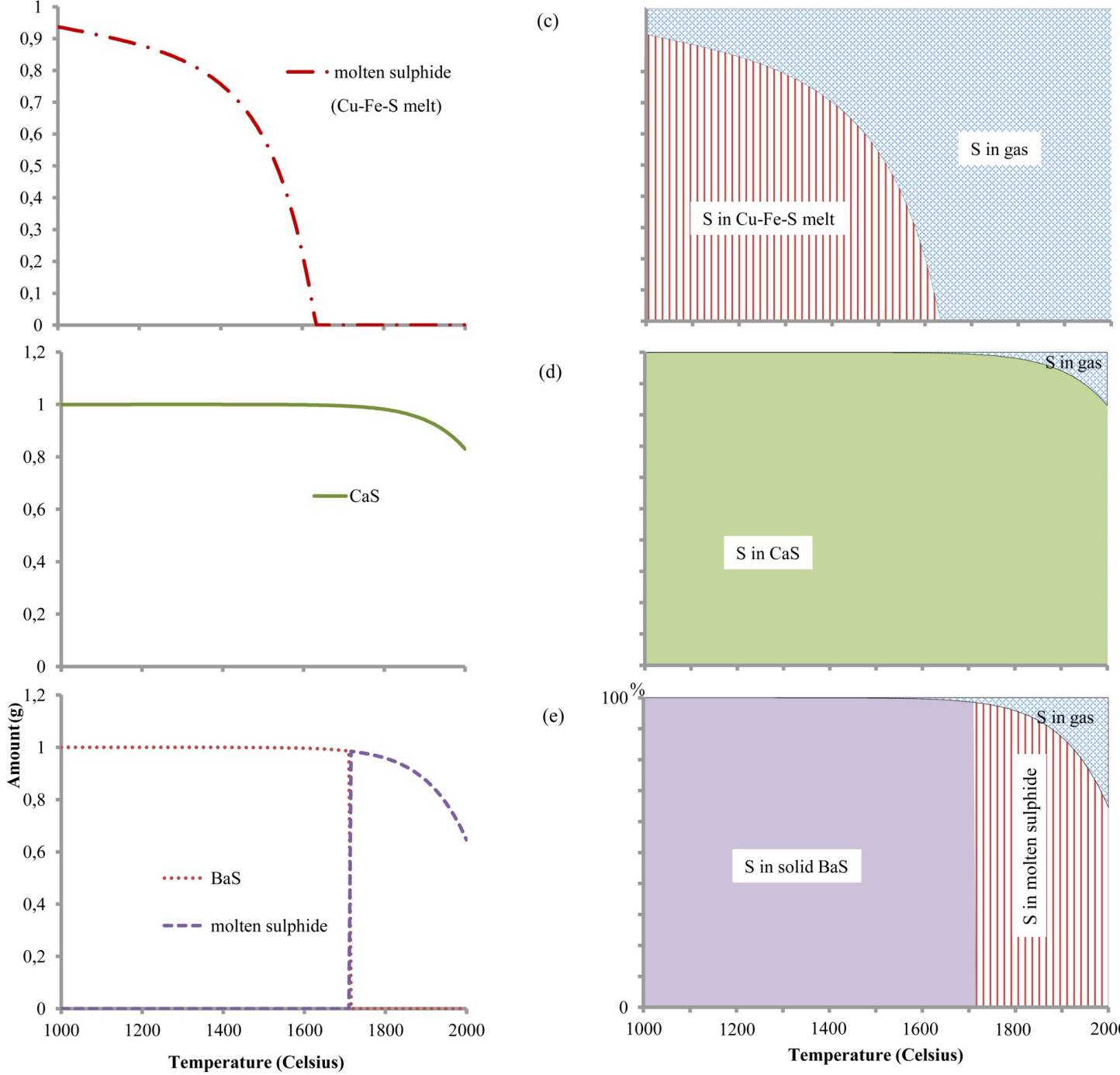

(e)

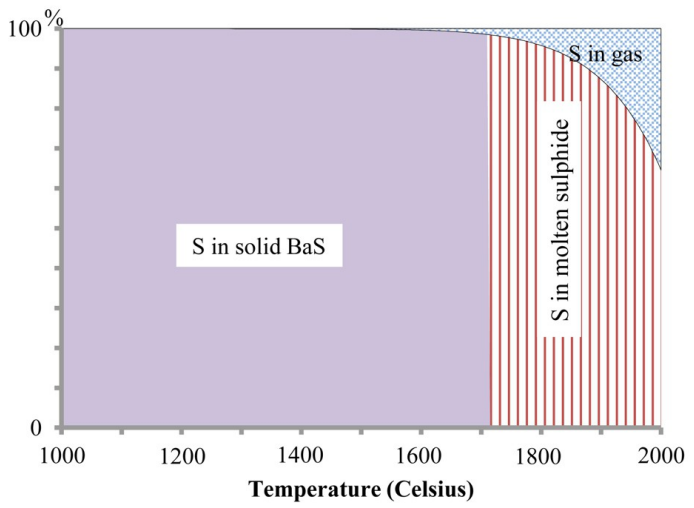

Figure 4. Transformations of suphur-bearing mineral phases (left column), and concentration of sulphur (right column) in mineral-carbon-gas (BF) system at 1000-2000 ${ }^{\circ} \mathrm{C}$. (a) - pyrhhotite, (b) sphalerite-wurtzite, (c) - molten sulphide (Cu-Fe-S melt), (d) - CaS, (e) - BaS. 
If we compare Figure 3 and Figure 4 for the temperature range $1000-2000{ }^{\circ} \mathrm{C}$ (overlapping region for calculations under coking and BF conditions), the role of the gas phase for sulphur liberation can be seen. Under BF conditions, pyrrhotite will release more sulphur, even below $1000{ }^{\circ} \mathrm{C}$ (Figure 4a), compared to the coking process. So, the aggregates of pyrrhotite enclosed inside of coke matrix will be the source of sulphur in the cohesive zone of the BF, where the formation of droplets of molten iron is already started [26]. Under such circumstances, some amount of solid particles of pyrrhotite can probably be captured by droplets of molten iron, when the particles will appear on the surface of the BF coke upon its consumption (Figure 5). Similar approach can be used to describe the behaviour of other sulphur-bearing minerals under the coking and BF conditions (Figure 5). Depending on the composition of molten iron (impurities) and the mineral phase presented in the system, the evolution of the mineral phase will take place. Some particles will be molten upon contact with the droplets, whereas others will be captured as solid sulphur-bearing inclusions. However, the details of such interactions are behind the scope of this study, and merit separate investigations.
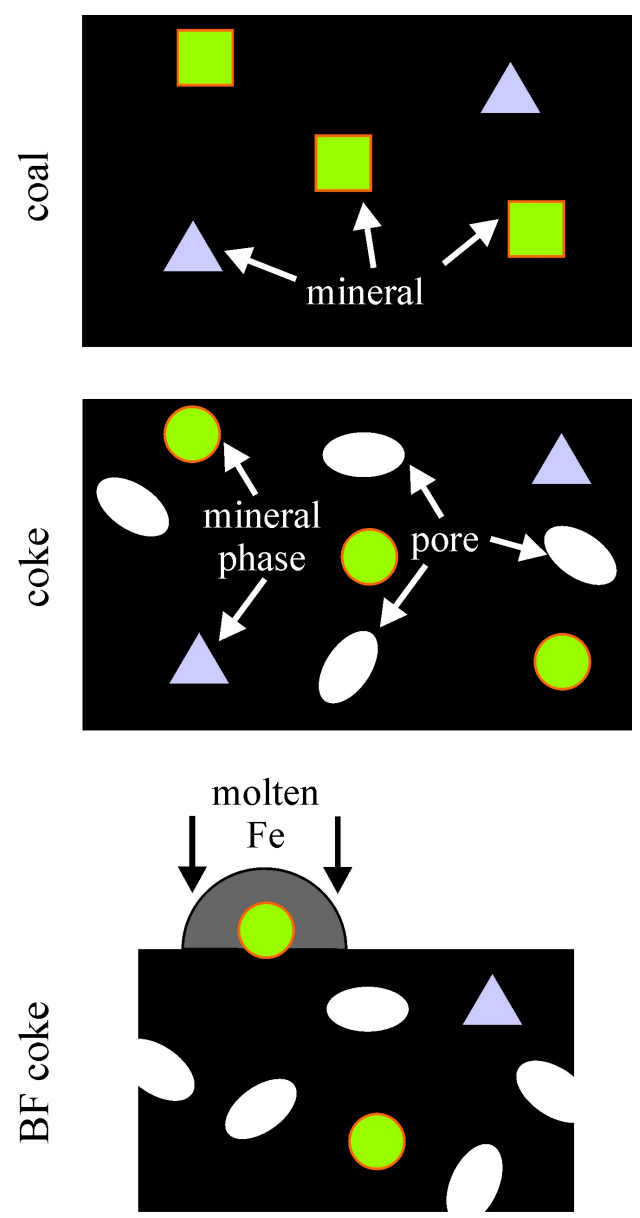

Figure 5. General model for occurrence and transformations of sulphur-bearings mineral phases in coal, coke and BF coke. 
The role of gas phase for sulphur release from the minerals is more evident in the $\mathrm{Zn}-\mathrm{S}$ system. At the end of the coking process, $\left(1200^{\circ} \mathrm{C}\right) 52.39$ wt. \% of S (Table 3) remains in mineral form, whereas under BF conditions (Figure 4b), whole sulphur will be released c. at $1050{ }^{\circ} \mathrm{C}$. As for $\mathrm{CaS}$ and $\mathrm{BaS}$, these compounds will survive the highest temperatures as solid phases, keeping sulphur in mineral form in the lower part of the $\mathrm{BF}$ and, then, with or without transformations, sulphur-bearing inclusions can be found in steels $[27,28]$. Based on that, we also suggest that in order to achieve better results in using of $\mathrm{Ca}$-bearing additives $\left(\mathrm{CaCO}_{3}\right)$ for improving of coke reactivity in the $\mathrm{BF}$ [29], preliminary evaluation of sulphur content and occurrence (mineral form) in coking coals can be helpful. This is because the excessive amount of mineral-related sulphur in mineral phases with relatively low decomposition temperature can be captured by $\mathrm{Ca}$, with subsequent formation of $\mathrm{CaS}$, which can further migrate into steel.

\section{Conclusions}

Based on the observations and discussion above, the following conclusions can be drawn:

- The major coal-associated sulphur-bearing minerals include sulphides (pyrite, sphalerite, galena, chalcopyrite and arsenopyrite) and sulphates (anhydrite and barite). Depending on the initial mineral in the coal, sulphur-bearing minerals will be transformed at the end of coking process into the following phases: pyrrhotite, wurtzite, $\mathrm{Cu}-\mathrm{Fe}-\mathrm{S}$ melt, $\mathrm{CaS}$ and $\mathrm{BaS}$;

- The amount of sulphur that will be kept in the coke in mineral form at the end of the coking process increases in the order of: galena $\rightarrow$ pyrite $\rightarrow$ sphalerite $\rightarrow$ arsenopyrite $\rightarrow$ chalcopyrite $\rightarrow$ anhydrite $\rightarrow(=)$ barite. Galena is most preferred mineral in terms of sulphur liberation (100\%) during the coking process;

- $\mathrm{CaS}$ and $\mathrm{BaS}$ are the most stable sulphur-bearing phases formed after sulphur-bearings minerals (mostly anhydrite and barite) of coking coals, therefore the coals with high concentrations of $\mathrm{Ca}$ and $\mathrm{Ba}$ combined with $\mathrm{S}$ should be avoided for coking purposes, when possible. Addition of $\mathrm{Ca}$ to coke to improve its reactivity should be done with caution when an elevated amount of sulphur is present in coking coals;

- Intensive gas flow under BF conditions facilitates liberation of sulphur from mineral phases in Fe-S, and especially in the Zn-S system. Complete elimination of mineral-related sulphur from coke under BF conditions takes place above $2000{ }^{\circ} \mathrm{C}$. 


\section{Acknowledgements}

This research was funded by the Academy of Finland. We thank Mr. Tommi Kokkonen for preparing the samples. Anonymous reviewers have provided valuable comments which improved clarity and quality of the manuscript.

\section{References}

[1] R. B. Finkelman. Modes of occurrence of trace elements in coal. 1981. Open-File Report 8199. U.S. Geological Survey. 1-315.

[2] S. Dai, T. Li, Y. Jiang, C. R. Ward, J. C. Hower, J. Sun, J. Liu, H. Song, J. Wei, Q. Li, P. Xie and Q. Huang, Int. J. Coal Geology 2015, 137, 92.

[3] D. Misch, D. Gross, Q. Huang, F. Zaccarini and R. F. Sachsenhofer, Int. J. Coal Geology 2016, 168-1, 108.

[4] S. I. Rudyuk, E. I. Fel'dman, E. I. Chernov, V. F. Korobeinik, Metal Science and Heat Treatment 1974, 16, 1056.

[5] B. Lv, F. C. Zhang, M. Li, R. J. Hou, L. H. Qian and T. S. Wang, Materials Science and Engineering: A 2010, 527, 5648.

[6] G. Xiao, H. Dong, M. Wang and W. Hui, J of Iron and Steel Res Int. 2011, 18, 58.

[7] M. Fang and S. Mantang, Metallurgist 2014, 58, 579.

[8] M. Iljana, O. Mattila, T. Alatarvas, J. Kurikkala, T. Paananen and T. Fabritius T. ISIJ Int. 2013, 53, 419 .

[ 9] Y. Gu, J. Yperman, G. Reggers, R. Carleer and J. Vandewijngaarden, Fuel 2016, 184,304.

[10] K. C. Hackley, R. R. Frost, C. L. Liu, S. J. Hawk and D. D. Coleman, Study of sulfur behavior and removal during thermal desulfurization of Illinois coals. Illinois State Geological Survey Circular 1990, C545, Champaign, Illinois, 1-33.

[11] J. W. Patrick, Fuel 1993, 72, 281.

[12] C. R. Ward, Int. J. of Coal Geology 2002, 50, 135.

[13] H. J. Gluskoter, Energy Sources 1977, 3, 125.

[14] S. Dai, Y. Zhou, D. Ren, X. Wang, D. Li and L. Zhao, Science in China Series D: Earth Sciences 2007, 50, 678.

[15] S. Gornostayev, J. Härkki and O. Kerkkonen. Fuel 2009, 88, 2032. 
[16] C. W. Bale, P. Chartrand, S. A. Degterov, G. Eriksson, K. Hack, R. Ben Mahfoud, J. Melancon, A. D. Pelton and S. Petersen. Calphad 2002, 26, 189.

[17] S. S. Gornostayev, E-P Heikkinen, J. J. Heino, S. M. M. Hutunen and T. M. J. Fabritius, Steel Research Int. 2016, 87, 1144.

[18] H. Liao, B. Li and B. Zhang, Fuel 1998, 77, 1643.

[19] G. Quinn, B. Faraj, R. Callcott and T. Callcott, Elucidation of the effects of minerals on coke behaviour in the blast furnace, Australian Coal Association Research Program, Project C10054, Australian Coal Research Limited, Brisbane, Australia 2002, 1-80.

[20] D. L. Whitney and B. W. Evans, American Mineralogist 2010, 95, 185.

[21] K. Murakami, Y. Shimamura and H. Tanaka, Gypsum \& Lime 1957, 31, 1522.

[22] S. S. Gornostayev, O. Kerkkonen and J. J. Härkki, Steel Research Int. 2009, 80, 390.

[23] S. Gornostayev, O. Kerkkonen and J. Härkki, ISIJ Int. 2005, 45, 1.

[24] S. Gornostayev and J. Härkki, Fuel 2006, 85, 1047.

[25] O. Kerkkonen, Coke Making Int. 1997, 9(2), 34.

[26] S. Ghosh, N. N. Viswanathan and N. B. Ballal, Steel Research Int. 2017, 88, (in press).

[27] Y. Wang, S. Sridhar and M. Valdez, Metallurgical and Materials Trans B 2002, 33B, 625.

[28] F. Jones, P. Jones, R. De Marco, B. Pejcic and A. L. Rohl, Applied Surface Science 2008, 254,3459 .

[29] S. Nomura, T. Tahara, S. Matsuzaki, M. Naito, H. Ayukawa, S. Koizumi, T. Abe and H. Kitaguchi, Improvement in blast furnace reaction efficiency through the use of catalyst-doped highly reactive coke. Report 94, Nippon Steel Technical Report, 2006, 109-114. 